\title{
KONSEPSI PEMBAGIAN KEKUASAAN NEGARA ISLAM KHILAFAH MENURUT HIZBUT TAHRIR DAN KEMUNGKINAN IMPLEMENTASINYA DI INDONESIA
}

\author{
Ahmadi H. Dardiri \\ Fakultas Syari'ah Institut Agama Islam Negeri Salatiga \\ Email : acanmusica@gmail.com
}

\begin{abstract}
Abstrak
The Islamic state idealized by Hizb ut-Tahrir has a system of government that is different from the existing system of government in the world today. The Islamic state has a different concept of power-sharing which is known in the growing doctrine of constitutional law. The concept of power sharing is similar to the concept of a state led by a king, since the caliph as head of state and head of government is given a very wide authority even including both judicial and legislative powers. This vast authority was given to the Caliph as an implementation of sovereignty in the hands of the Ummah who was then used to elect a caliph, so that the authority of the state derived from the Ummah was called by a caliph. The author analyzes the concept of the division of powers of Islamic countries according to Hizb ut-Tahrir to be applied in Indonesia which is a country with a majority of its population is Muslim. This analysis is based on the development of Indonesian constitutional phases since the founding of this country until today in order to find the possibility of conception to implementation of power sharing Khilafah Hizb ut-Tahrir Islamic state in Indonesia. This study suggests to Hizb ut-Tahrir for reconstruction and ijtihad new as "qoul al-jadid" to the concept of power-sharing formulated within the Islamic state Khilafah Hizb to be implemented in Indonesia and can help overcome the problems of the people associated with the concept of the Indonesian state administration, especially in the field of The division of state power.
\end{abstract}




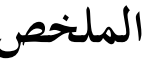

الدولة الإسلامية المنشودة من قبل حزب التحرير لديها نظام الحكومة المختلف من نظام الحكومة التي توجد في العالم اليوم. الدولة الإسلامية في تطورها لديها مفهوم تقسيم السلطة المختلف مما يعرف في مفهوم تطور القانون الدستوري. تقسيم السلطة لحزب التحرير يكاد يساوي مع مفهوم دولة يحكمها ملك، لأن الخليفة كرئيس الدولة

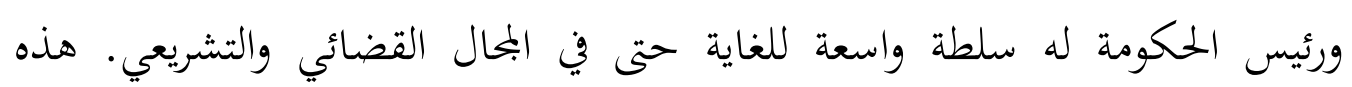
السلطة الهائلة الممنوحة للخليفة باعتبارها تنفيذ السيادة في يد الشعب التي تستخدم

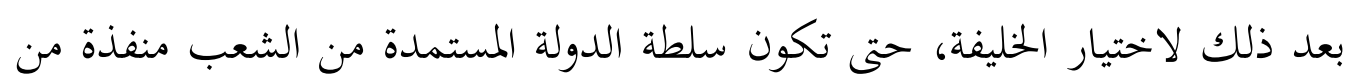

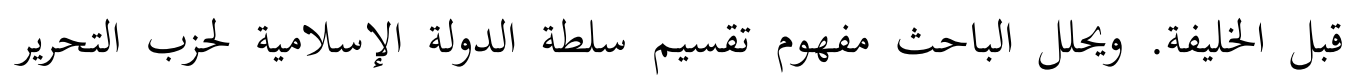
لأجل تنفيذه في إندونيسيا بوصفها دولة ذات أغلبية مسلمة. ويستند هذا التحليل

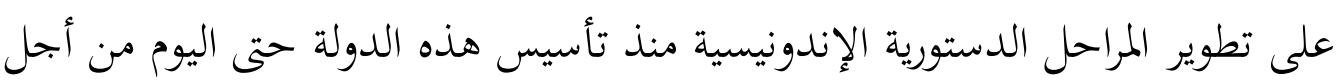

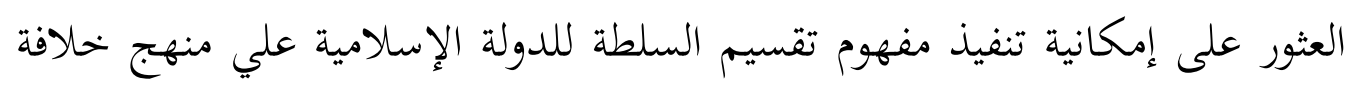
حزب التحرير في اندونيسيا. وتشير هذه الدراسة إلى حزب التحرير لإعادة البناء

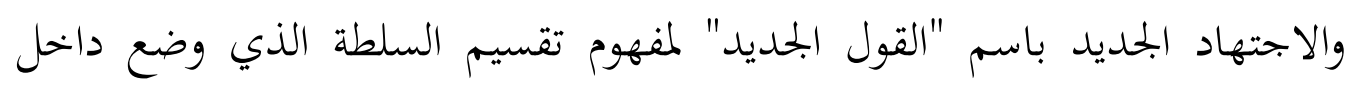
الدولة الإسلامية علي منهج خحلافة حزب التحرير المزمع تنفيذه في إندونيسيا ويمكن

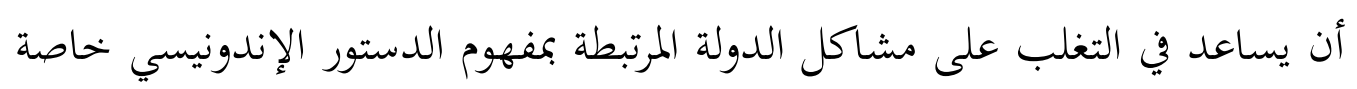
في بحال تقسيم سلطة الدولة.

Keywords: Hizbut Tahrir, Negara Islam Khilafah, Pembagian kekuasaan.

\section{A. Pendahuluan}

Hizbut Tahrir merupakan sebuah organisasi politik yang berideologi Islam. Mereka bergerak ditengah ummat dan berjuang untuk menjadikan Islam sebagai 
solusi dari segala permasalahan yang terjadi, serta membimbing mereka untuk mendirikan kembali sistem Khilafah dan menegakkan hukum yang diturunkan Allah dalam realitas kehidupan. Dalam pandangannya, Hizbut Tahrir menilai bahwa selama ini pergerakan yang muncul di kalangan kaum muslimin di negara-negara Islam hanya sebatas pada sosial-kemasyarakatan dan jarang ada yang mengarah pada politik, bahkan gerakan yang mereka lakukan hanya sebatas pada pembenahan masyarakat yang parsial dan tidak menyeluruh dan menurut pandangan mereka ini merupakan sebuah kesalahan. Perubahan harus dilakukan dengan total dan menyeluruh. ${ }^{1}$

Problematika yang terjadi di Indonesia ini menurut mereka dikarenakan tidak berpangkalnya kedaulatan As syar'i yang digunakan oleh Indonesia. Dengan kata lain, tidak diterapkannya sistem Islam di Indonesia menjadikan munculnya permasalahan seperti korupsi, kemiskinan, kerusakan moral dan sebagainya, ${ }^{2}$ sehingga Daulah Khilafah merupakan sebuah solusi yang tepat dalam memperbaiki segala permasalahan yang ada di dunia, khususnya Indonesia. Konsep negara Khilafah di Indonesia, dalam sejarahnya, telah diterapkan sejak abad ke 7. Hal ini bisa diihat dari adanya beberapa lembar fakta sejarah telah mencatat dengan jelas dan otentik terhadap jejak penerapan syariah di Sumatera dan jalinan kerjasama para sultan dengan institusi politik internasional Islam (Khilafah Islam). ${ }^{3}$

Sistem negara Khilafah yang diusung oleh Hizbut Tahrir ini memiliki konsep yang telah dirumuskan oleh Hizbut Tahrir dengan baik, hal ini bisa dilihat dari adanya rancangan konstitusi, ${ }^{4}$ struktur lembaga negara, ${ }^{5}$ dan tugas-tugasnya dalam menjalankan roda pemerintahan Khilafah. Negara Khilafah ini memiliki

1 Ainur Rofiq Al-amin, Membongkar Proyek Khilafah ala Hizbut Tahrir di Indonesia, Cetakan II (Yogyakarta : LKiS, 2012), hal. 27

2 Hizbut Tahrir Indonesia, Manifesto Hizbut Tahrir untuk Indonesia (Indonesia, khilafah dan penyatuan kembali dunia Islam) http:/ / hizbut-tahrir.or.id/2007/12/11/mafahim-hizbuttahrir/ diakses pada tanggal 5 Februari 2016.

3 Asmaul Husna, Jejak Syari'ah dan Khilafah di Sumatra, http://hizbut-tahrir. or.id/2007/06/12/jejak-syariah-khilafah-di-sumatera/diakses pada tanggal 5 Februari 2016.

4 Lebih detailnya dapat dilihat dalam buku Ad Daulah Al Islamiyyah yang ditulis oleh Taqiyyuddin an-Nabhani.

5 Lebih detailnya tentang struktur lembaga negara ini dapat dilihat dalam buku Ajhizah Daulatul Khilafah yang dikeluarkan oleh Hizbut Tahrir, diterjemahkan dalam bahasa Indonesia dengan judul Struktur Negara Khilafah (Pemerintahan dan Administrasi). 
empat pilar yang wajib ada demi keberadaan dan kelangsungan keberadaan negara Khilafah. Jika salah satu pilar ini tidak ada, berarti negara Khilafah tidak ada atau telah berubah menjadi bentuk negara atau sistem pemerintahan lain yang tidak islami, keempat pilar tersebut yaitu (1) kedaulatan di tangan syariah, bukan di tangan rakyat; (2) kekuasaan di tangan umat; (3) mengangkat satu orang khalifah adalah wajib atas seluruh kaum muslimin; dan (4) hanya khalifah saja yang berhak melegislasikan hukum-hukum syara', dan khalifah saja yang berhak melegislasi UUD dan segenap UU. ${ }^{6}$

Pemahaman mengenai wajibnya mendirikan negara Khilafah ini, Hizbut Tahrir mendasarkan pada perkataan Imam Ibnu Hazm, Syeikh Abdurrahman al-Jaziri, dan Syeikh Abdul Qodim Zallum (Amir kedua Hizbut tahrir) yang pada dasarnya menyatakan bahwa para Ulama' telah sepakat, baik dari Ahlu Sunnah, Murji'ah, Syiah dan Khawarij, untuk membentuk Khilafah. ${ }^{7}$ Pendapat ini juga didukung dengan dalil al-Qur'an Surat An-nisa: 59. ${ }^{8}$

Meski konsep negara Khilafah ini didasarkan kepada al-Quran dan dengan tujuan untuk dapat mengimplementasikan syari'at Islam sebagai landasan berperilaku masyarakatnya. Konsep ini ternyata tidak dapat diterima begitu saja oleh kalangan umat Islam terutama di Indonesia. Banyak para pakar Islam di Indonesia yang tidak sepakat dengan adanya konsep Khilafah atau negara Islam ini sebagaimana yang diungkapakan oleh Abdurrahman Wahid dalam bukunya bahwa beliau tidak menemukan adanya konsep negara Islam, menurutnya Islam sebagai jalan hidup tidak memiliki konsep yang jelas tentang negara Islam. ${ }^{9}$ Hal ini didasarkan pada dua hal, pertama, Islam tidak mengenal pergantian pemimpin dan kedua, tidak jelasnya ukuran konsep negara yang

6 M.ShiddiqAl-Jawi, Empat PilarNegara Khilafah,http:/ / hizbuttahrir.or.id/2012/06/13/ empat-pilar-negara-khilafah/ diakses pada tanggal 5 Februari 2016.

7 Lajnah Tsaqofiyyah Hizbut Tahrir, Jawaban Tuntas Pertanyaan Berulang Seputar Khilafah dan Hizbut Tahrir, http://hizbut-tahrir.or.id/2012/09/05/jawaban-tuntas-pertanyaanberulang-seputar-khilafah-dan-hizbut-tahrir/ diakses pada tanggal 5 Februari 2016.

8 Qs. An Nisa: 59 (Hai orang-orang yang beriman, taatilah Allah dan taatilah Rasul (Nya), dan ulil amri di antara kamu. Kemudian jika kamu berlainan Pendapat tentang sesuatu, Maka kembalikanlah ia kepada Allah (Al Quran) dan Rasul (sunnahnya), jika kamu benar-benar beriman kepada Allah dan hari kemudian. yang demikian itu lebih utama (bagimu) dan lebih baik akibatnya)

9 Abdurrahman Wahid, Islamku, Islam Anda Islam Kita; Agama Masyarakat Negara Demokrasi, Cetakan II, (Jakarta : The Wahid Institute, 2006), hal. 81 
didasarkan pada Islam. ${ }^{10}$ Pendapat ini didukung oleh Dhiauddin Rais yang menyatakan bahwa Islam tidak mewariskan kepada pemeluknya aturan-aturan siap pakai dalam bidang politik sebagaimana dalam bidang akidah. ${ }^{11}$

Prof. Dr. Syed Hussain Mohammad Jafri, Ph.D juga mengungkapkan hal serupa, menurutnya, al-Qur'an tidak sedikitpun mengindikasikan bahwa nabi diberi tugas untuk mendirikan otoritas negara atau politik sebagai bagian dari misi keagamaan. Negara merupakan bentuk implikasi dari ajaran agama yang bersifat individual, ${ }^{12}$ sehingga Negara Islam atau negara Khilafah yang diusung oleh Hizbut Tahrir ini seharusnya tidak dilegitimasi secara agama dalam prakteknya, meskipun begitu, pada dasarnya konsep negara Khilafah yang mendasarkan pada Islam ini bertujuan untuk memperbaiki problematika umat yang tidak dapat diselesaikan.

Selain mendapatkan pertentangan dari dasar didirikannya negara Khilafah, konsep negara Khilafah juga menuai kritik didalam pelaksanaan pemerintahannya. Ahmad Fuadi Fanani, dalam tulisannya di Kompas (Sabtu, 26 Februari 2005) menyatakan bahwa sistem pemerintahan negara Khilafah merupakan bentuk sistem ketatanegaraan yang tirani. Hal ini didasarkan pada dua hal. Pertama, sistem ini menganut kedaulatan di tangan Tuhan. Kedua, Sistem ini tidakada Trias Politica ${ }^{13}$. Kekuasaan absolutyang dimilikiolehkhalifah ini memberikan kesempatan baginya untuk melakukan penyalahgunaan kekuasaan yang dimilikinya.

Pendapat diatas mendapatkan tanggapan dari aktivis Hizbut Tahrir, Muhammad Ismail Yusanto, yang menyatakan bahwa terdapat kesalahan dalam pemahaman Ahmad Fuadi Fanani. Dia menjelaskan bahwa khalifah dalam sistem negara khilafah tidak memiliki kekuasaan yang absolut. Hal ini dikarenakan khalifah dibatasi oleh syara', sehingga dalam pelaksanaan

10 Ibid, hal. 82- 83 .

11 Dhiauddin Rais, Teori Politik Islam, diterjemahkan oleh Abdul Hayyie al-Kattani, Andi Aderus Banua,dkk, cetakan I, ( Jakarta Gema Insani Press : 2001), hal.9.

12 Syed Hussain Mohammad Jafri, Agama dan Negara dalam Pandangan Imam Ali, Cetakan I, (Yogyakarta : Rausyanfikr Institute, 2012), hal. 4-5.

13 Muhammad Ismail Yusanto, Menjawab Kritikan terhadap Konsep Khilafah http:// hizbut-tahrir.or.id/2007/07/10/menjawab-kritikan-terhadap-konsep-khilafah/diakses pada tanggal 10 Februari 2016. 
pemerintahannya khalifah tidak mungkin dapat menyalahgunakan kekuasaan yang diberikan kepadanya. ${ }^{14}$

Berdasarkan dua pendapat yang telah diuraikan diatas, terdapat kesimpangsiuran terkait dengan kekuasaan absolut yang dimiliki oleh Khalifah dalam sistem negara Islam Khilafah yang dirumuskan oleh Hizbut Tahrir, oleh karena itu penulis ingin menggali kebenaran tentang kekuasaan negara dalam konsep negara Khilafah perspektif Hizbut Tahrir dan kemungkinan diterapkannya sistem pembagian kekuasaan negara Khilafah tersebut di Indonesia yang mayoritas penduduknya beragama Islam.

\section{B. Pembagian Kekuasaan Negara Khilafah Hizbut Tahrir}

Pada dasarnya, negara Khilafah Hizbut Tahrir memiliki sistem yang berbada dalam penyelenggaraan negaranya dengan semua sistem yang diterapkan di negara modern. Hizbut Tahrir melandaskan sistem pemerintahannya kepada ajaran agama Islam yang disandarkan pada keseluruhan praktek ketatanegaraan, yang dianggap oleh Hizbut Tahrir sebuah keberhasilan dalam mendirikan negara Khilafah, yang dijalankan oleh Rasulullah pada saat beliau menyebarkan ajaran agama Islam. ${ }^{15}$ Meskipun negara Khilafah tidak menerapkan sistem pemerintahan yang popular digunakan masyarakat saat ini, akan tetapi tujuan dari berdirinya negara Khilafah ini adalah untuk menyelesaikan problematika umat yang terjadi dan mengimplementasikan nilai- nilai agama.

Negara Islam Khilafah memiliki rancangan undang- undang dasar tersendiri negara ini dapat berdiri dalam suatu wilayah. Rancangan kostitusi ini berjumlah 190 pasal yang terdiri dari hukum- hukum umum, Sistem Pemerintahan, Khalifah, Muawwin at Afwidl, Muawwin at Tanfidz, al Wulat, Amirul Jihad, Departemen keamanan dalam negeri dan luar negeri, Direktorat Perindustrian, al Qadla, Jihaz al Idari, Baitul Mal, Departemen penerangan, majelis al-Ummah, sistem sosial, sistem ekonomi, politik pendidikan dan politik luar negeri. ${ }^{16}$

\footnotetext{
14 Ibid,

15 Adi Victoria, Khilafah the answer; Catatan Ideologis seputar dakwah dan syari'ah, Cetakan I, (Yogyakarta : Kutlah Media, 2012), hal. 226.

16 Taqiyyudin an-Nabhani, Daulah Islam Taqiyyuddin An-Nabhani, Daulah Islam, terj. Umar Faruq, dkk, Ctk. 4, (Jakarta : HTI- Press, 2009), hal.295-338.
} 
Rancangan undang-undang dasar yang dibuat oleh hizbut Tahrir ini menjelaskan adanya kekuasaan negara Khilafah yang dimiliki oleh lembaga negara dalam struktur negara Khilafah. Kekuasaan yang diberikan kepada Khalifah dalam negara ini sangatlah besar. Ainur Rafiq al-Amin menjelaskan dalam bukunya bahwa Taqiyuddin an-Nabhani menyatakan dalam rancangan undang-undang dasar negara Khilafah bahwa khalifah memiliki wewenang yang sangat luas. Nabhani juga menyebutkan bahwa Khalifah adalah negara itu sendiri, ${ }^{17}$ dan adalah sebuah negara serta memiliki seluruh kekuatan dan fungsi negara. ${ }^{18}$

Pernyataan Nabhani tersebut memiliki konsekuensi bahwa Khalifah memiliki kekuasaan yang sangat besar dalam tata penyelenggaraan negara. Kekuasaan negara secara keseluruhan berada di dalam tangan khalifah sebagai kepala negara dan kepala pemerintahan. Selain sebagai pelaksana pemerintahan atau eksekutif sebagaimana yang dikenal saat ini, khalifah juga memiliki kewenangan dalam hal melegislasi undang- undang atau legislatif dan juga secara posisi juga berada diatas qadhi qudhat sebagai pemegang kekuasaan tertinggi dalam bidang yudikatif.

Rancangan undang undang negara Khilafah memberikan wewenang kepada khalifah dalam pasal 36. Pasal 36 huruf (d) menjelaskan bahwa Khalifah memiliki wewenang untuk memberhentikan dan menentukan para Muawwin dan para wali, sementara pada pasal 36 huruf (b) dan (c) menjelaskan bahwa khalifah bertanggung jawab dalam pelaksanaan politik negara, penerimaan, dan penolakan duta-duta asing serta kewenangan memberhentikannya. ${ }^{19}$

Kewenangan diatas merupakan kewenangan yang dimiliki oleh lembaga eksekutif karena berkaitan dengan pelaksanaan pemerintahan, meskipun terkadang dalam penentuan wali (gubernur) dalam suatu negara biasanya diadakan dengan adanya pemilihan oleh rakyat atau pun bisa melalui penunjukan karena dianggap sebagai kepanjangan tangan dari kepala pemerintahan.

17 Hal ini diungkapkan dalam buku an-nabhani sebelum adanya rivisi yang terbaru pada tahun 2005, akan tetapi setelah adanya revisi tulisan ini dihapus di dalam rancangan undang- undang dasar negara Islam khilafah.

18 Hizbut Tahrir, Struktur Negara Khalifah (Pemerintahan dan Administrasi), terj. Yahya A.R, Ctk. Ketiga, (Jakarta : HTI-Press, 2008), hal.182.

19 Taqiyyudin an-Nabhani, Daulah Islam..., op. cit., hal. 302-303. 
Jabatan para wali dan para muawwin yang ditentukan oleh khalifah ini tentunya memiliki konsekuensi atas pertanggungjawaban dalam melaksanakan kewajiban yang telah diberikan kepadanya. Para wali dan muawwin bertanggung jawab kepada khalifah dan bertanggungjawab kepada majelis alummah sebagai lembaga penyalur aspirasi rakyat.

Khalifahjuga memiliki kewenangan dalam hal bidanglegislasi, kewenangan ini selain dijelaskan dalam empat pilar dasar negara khalifah, juga terdapat dalam rancangan undang- undang dasar negara Khilafah pasal 36 huruf (a) dan huruf (f) bahwa hanya khalifah yang berhak meligislasi hukum-hukum syara' yang diperlukan untuk memelihara urusan umat dan menentukan hukumhukum syara' yang berhubungan dengan anggaran pendapatan dan belanja negara. ${ }^{20}$

Khalifah berhak melegislasi syara' atau hukum dengan ijtihad dengan dibatasi dari dua sumber hukum agama Islam yaitu al-Qur'an dan hadist. Apabila khalifah dalam melegislasi hukum melanggar syara' atau bertentangan dengan dua sumber utama hukum Islam, maka mahkamah madzalim berhak untuk menegur bahkan hingga memberhentikan seorang khalifah jika teguran dari mahkamah madzalim tidak di patuhi. Hal ini merupakan perbedaan dalam sistem negara Khilafah dengan semua sistem yang ada di negara- negara saat ini yang menganut sistem pembagian kekuasaan yang memisahkan antara kekuasaan wilayah eksekutif dengan wilayah legislatif.

Negara khilafah, dalam rancangan undang- undang dasarnya, juga memberikan kekuasaan kehakiman atau yang biasa disebut dengan kekuasaan yudikatif terhadap khalifah. Hal ini bisa dilihat pada pasal 36 huruf (e) terkait dengan kewenangan khalifah dalam menentukan dan memberhentikan seluruh qadhi atau hakim. Pengecualian yang diberikan dalam pasal ini hanya untuk pemberhentian seorang qadhi madzalim yang sedang menangani perkara khalifah, muawwin atau qadhi qudhat. ${ }^{21}$

Pengecualian yang diberikan terhadap khalifah dalam pemberhentian terhadap qadhi madzalim ini diberikan sebagai upaya preventif agar tidak terjadi penyalahgunaan kekuasaan yang dilakukan oleh khalifah apabila perkaranya sedang disidangkan oleh hakim tersebut, sehingga kewenangan terkait dengan

\footnotetext{
20 Ibid, hal. 303.

21 Hizbut Tahrir, Struktur Negara Khilafah ..., op. cit., hal. 203.
} 
pemberhentian ini ditiadakan. Namun, untuk kewenangan pemberhentian qadhi madzalim, selain dalam kondisi menangani perkara khalifah, muawwin dan qadhi qudhat, tetap berada di tangan khalifah. ${ }^{22}$

Negara Islam Khilafah Hizbut Tahrir ini memberikan kekuasaan negara khalifah kepada khalifah sangat luas dan tiga kekuasaan yang biasanya dibagikan terhadap tiga lembaga ini disatukan dalam kekuasaan seorang Khalifah dengan batasan- batasan yang diatur dalam rancangan undangundang dasar negara tersebut sebagaimana dijelaskan diatas.

\section{Analisis Penerapan Pembagian Kekuasaan Negara Islam Khilafah Hizbut Tahrir di Indonesia}

Konsepsi Pembagian kekuasaan negara Islam Khilafah Hizbut Tahrir, meskipun pada dasarnya dibuat untuk melengkapi konsep negara Islam Khilafah mereka, tentunya dirumuskan agar penyelenggaraan pemerintahan dalam sebuah negara pada umumnya dapat berjalan dengan baik sesuai dengan prinsip-prinsip ajaran Islam. Hal mendasar yang menyatakan bahwa konsep negara ini berasal dari agama Islam perlu dibuktikan dengan pedoman syariat Islam yang bersifat "rahmatan lil alamin" dan "sholihun li kulli zaman wa li kulli makan". Oleh karena itu konsepsi pembagian kekuasaan ini perlu dianalisis kemungkinan implementasinya di Indonesia yang merupakan negara mayoritas penduduknya beragama Islam

Indonesia merupakan sebuah negara yang menganut pemisahan kekuasaan yang pada dasarnya teori ini dicetuskan oleh Montesquieu, meskipun pada implementasinya banyak perubahan dan variasi dari konsep dasarnya. Perubahan tersebut diterapkan semata-mata karena kebutuhan masyarakat. Analisis terkait dengan konsepsi pembagian kekuasaan negara Islam Khilafah Hizbut Tahrir ini akan penulis bagi menjadi tiga bagian berdasarkan sudut pandang teori pembagian kekuasaan negara, hal ini dikarenakan Indonesia dalam pelaksanaan pemerintahannya juga menganut konsepsi pembagian kekuasaan ini, sehingga analisis ini dapat sesuai dengan wilayah dimana konsepsi pembagian kekuasaan negara Islam Khilafah Hizbut Tahrir ini diterapkan. 


\section{Analisis Penerapan Konsep Kekuasaan Legislatif Negara Islam Khilafah Hizbut Tahrir di Indonesia.}

Legislatif merupakan salah satu bagian dari kekuasaan negara yang dipisahkan dari kekuasaan mutlak yang dimiliki oleh negara dalam pelaksanaan pemerintahannya. Badan legislatif ini merupakan manifestasi dari berkembangnya gagasan kedaulatan ditangan rakyat, Rousseau sebagai seorang pelopor kedaulatan rakyat pada awalnya mencita-citakan demokrasi langsung sebagaimana yang dilakukan di Jenewa ketika rakyat secara langsung dapat merumuskan dan merundingkan soal ketatanegaraannya, akan tetapi hal ini dianggap tidak efektif, sehingga perlu adanya sebuah lembaga yang isi oleh perwakilan rakyat yang dipilih langsung oleh rakyat. ${ }^{23}$

Fungsi badan legislatif yang terpenting adalah menentukan kebijakan atau undang-undang dan mengontrol badan eksekutif dalam pelaksanaan tugas pemerintahannya sesuai dengan kebijakan- kebijakan yang telah ditetapkan tersebut. ${ }^{24} \mathrm{Hal}$ ini dikarenakan lembaga ini merupakan manifestasi dari rakyat sebagai pemegang kekuasaan tertinggi dalam negara, sehingga kebijakan yang telah ditetapkan oleh lembaga ini merupakan kebijakan yang mewakili keinginan warga negara tersebut.

Lembaga legislatif, dalam konsep negara Islam Hizbut Tahrir, tidak ditemukan secara eksplisitnamalembaga pemegang kekuasaanlegislatifini. Dua fungsi penting yang terdapat dalam badan legislatif ini justru dimiliki oleh dua lembaga negara yang berbeda dalam negara Khilafah Hizbut Tahrir. Kekuasaan untuk pembuatan kebijakan atau undang- undang dimiliki oleh seorang Khalifah, sementara kewenangan pengawasan terhadap penyelenggaraan pemerintahan diberikan kepada lembaga majelis al-ummah.

Kekuasaan pembuatan kebijakan atau undang-undang yang dimiliki oleh seorang khalifah dapat dilihat dalam rancangan undang-undang dasar negara Islam Khilafah Hizbut Tahrir pada pasal 3, pasal 4 dan pasal 36 huruf (a) yang berbunyi sebagai berikut.

\section{Pasal 3}

Khalifah melegislasi hukum- hukum syara' tertentu yang dijadikan sebagai undang- undang dasar dan undang- un-

23 Miriam Budiardjo, Dasar-dasar ..., op. cit., hal. 316.

24 Ibid, hal. 322. 
dang negara. Undang- undang dasar dan undang- undang negara yang telah disahkan oleh khalifah menjadi hukum syara' yang wajib dilaksanakan dan menjadi perundangundangan resmi yang wajib ditaati oleh setiap individu rakyat secara lahir maupun batin

Pasal 4

Khalifah tidak melegislasi hukum syara' apapun yang berhubungan dengan ibadah, kecuali masalah zakat dan jihad.Khalifah juga tidak melegislasi pemikiran apapun yang berkaitan dengan akidah Islam.

Pasal 36

Khalifah memiliki wewenang sebagai berikut:

(a) dialah yang melegislasi hukum- hukum syara' yang diperlukan untuk memelihara urusan- urusan umat, yang digali dari ijtihad yang shahih dari kitabullah dan sunnah rasul-Nya, sehingga menjadi perundangundangan yang wajib ditaati dan tidak boleh dilanggar. ${ }^{25}$

Khalifah memiliki kewenangan legislasi dalam perundang-undangan yang dibatasi dengan batasan tidak diperbolehkan melegislasi peraturan yang berhubungan dengan ibadah, selain zakat dan jihad, dan pemikiran yang berkaitan dengan akidah Islam, selain itu khalifah juga dibatasi kewenangan legislasinya dengan syara' yang berarti bahwa khalifah tidak boleh melegislasi peraturan yang bertentangan dengan syara' dan dua syarat yang menyatakan bahwa legislasi yang dilakukan berdasarkan ijtihad dengan metode ijtihad tertentu yang tidak boleh berubah dan tidak melegislasi peraturan yang bertentangan dengan peraturan sebelumnya. Hal ini sebagaimana tercantum dalam pasal 37 rancangan undang- undang dasar negara Islam Khilafah Hizbut Tahrir sebagaimana dibawah ini.

Pasal 37

Dalam melegislasi hukum, Khalifah terikat dengan hu-

25 Taqiyyudin an-Nabhani, Daulah Islam..., op. cit., hal. 295, 296 dan 302. 
kum-hukum syara'. Diharamkan atasnya melegislasi hukum yang tidak diambil melalui proses ijtihad yang benar dari dalil-dalil syara'. Khalifah terikat dengan metode ijtihad yang dijadikannya pedoman dalam pengambilan suatu hukum. Khalifah tidak dibenarkan melegislasi hukum berdasarkan metode ijtihad yang bertentangan dengan apa yang telah diadopsinya, dan tidak diperkenankan mengeluarkan perintah yang bertentangan dengan hukum- hukum yang telah dilegislasinya. ${ }^{26}$

Kewenangan Legislasi yang dimiliki oleh Khalifah ini bisa dikelompokkan pembatasannya dengan lebih jelas sebagai berikut

\begin{tabular}{|c|c|}
\hline \multirow{6}{*}{$\begin{array}{l}\text { Kewenangan } \\
\text { Legislasi Khalifah }\end{array}$} & Pembatasan \\
\hline & $\begin{array}{l}\text { 1. Tidak melegislasi peraturan ibadah kecuali zakat dan } \\
\text { jihad }\end{array}$ \\
\hline & 2. Tidak melegislasi pemikiran akidah \\
\hline & 3. Tidak boleh bertentangan dengan syara' \\
\hline & 4. Tidak bertentangan dengan peraturan sebelumnya \\
\hline & $\begin{array}{l}\text { 5. Berdasarkan ijtihad dengan metode ijtihad yang tidak } \\
\text { berubah }\end{array}$ \\
\hline
\end{tabular}

Legislasi yang dilakukan oleh khalifah ini boleh dimintakan pendapat terhadap majelis al-ummah, namun jika terdapat perbedaan pendapat terkait dengan metode ijtihad dalam melakukan legislasi, maka permasalahan untuk menentukan metode yang tepat digunakan dalam melegislasi kebijakan akan diputuskan oleh mahkamah madzalim dan keputusan ini wajib ditaati oleh khalifah.

Fungsi legislatif dalam pengawasan terhadap penyelenggaraan pemerintahan ini diberikan kepada majelis al-ummah sebagai lembaga representasi umat. Majelis al-ummah memiliki kewenangan mengkritik seorang khalifah dalam pelaksanaan pemerintahannya dan melakukan pemecatan secara tidak langsung kepada muawwin, wali dan amil yang merupakan kepanjangan tangan presiden dalam menjalankan roda pemerintahannya. Pemecatan terhadap muawwin, wali dan amir ini memang tidak dilakukan oleh majelis al-ummah secara langsung, karena pemecatan tersebut adalah

\footnotetext{
26 Ibid, hal. 303.
} 
kewenangan Khalifah, akan tetapi dalam hal adanya ketidaksenangan majelis ummat terhadap muawwin, wali dan amir ini, maka khalifah terikat untuk memberhentikan mereka. Hal ini bisa dilihat dalam pasal 111 ayat 3 dan 4 yang menjelaskan mengenai kewenangan majelis al-Ummah sebagaimana dibawah ini.

\section{Pasal 111}

Majelis al-Ummah memiliki 5 wewenang:

3. majelis al-Ummah berhak mengkritik khalifah terhadap seluruh aktivitas yang telah dilaksanakan di negara, baik yang menyangkut urusan dalam negeri, luar negeri, keuangan, angkatan bersenjata, maupun yang lainnya. Pendapat majelis al-Ummah bersifat mengikat dalam permasalahan yang didalamnya pendapat mayoritas mengikat. ${ }^{27}$ Dan pendapat majelis tidak bersifat mengikat dalam masalah yang pendapat mayoritas tidak mengikat. ${ }^{28}$ Jika Majelis alUmmah berbeda pendapat dengan khalifah dalam suatu aktivitas yang telah dilaksanakan dari aspek syar'i, maka hal itu dikembalikan kepada mahkamah madzalim untuk memastikan syar'i atau tidaknya aktivitas tersebut dan pendapat mahkamah madzalim dalam hal itu bersifat mengikat;

4. majelis al-Ummah berhak menampakkan ketidaksenanganya terhadap para muawwin, wali dan amil. Dan pendapat majelis dalam hal ini bersifat mengikat. Khalifah harus segera memberhentikan mereka.Jika pendapat majelis al-Ummah bertentangan dengan pendapat majelis wilayah tertentu dalam masalah keridhaan dan pengaduan atas wali dan amil, maka pendapat Majelis Wilayah lebih diutamakan dalam hal itu. ${ }^{29}$

27 Permaslahan yang menjadikan pendapat mayoritas dapat dijadikan sebagai keputusan yang mengikat dikarenakan dalam permasalahan tersebut adalah permasalahan dalam masalah politik dalam negeri yang tidak memerlukan pendalaman dan penelitian yang mendalam seperti urusan pemerintahan, pendidikan, kesehatan, ekonomi, perdagangan, industri, pertanian dan sejenisnya.

28 Permasalahan yang menjadikan pendapat majlis al ummah tidak mengikat adalah dikarenakan permasalahan ini memerlukan pembahasan mendalam dan penelitian seperti teknik, sains, keuangan, angkatan bersenjata dan politik luar negeri.

29 Taqiyyudin an-Nabhani, Daulah Islam..., op. cit., hal. 322. 
Pengaturan dalam negara Khilafah ini sangatlah berbeda dengan konsep yang diterapkan di Indonesia. Indonesia dalam hal pengaturan pembagian kekuasaan menempatkan sebuah kekuasaan legislastif kepada lembaga negara tertentu, jika menganut pada fungsi dari sebuah legislatif, maka ada 4 lembaga negara yang dapat dikategorikan masuk dalam kekuasaan legislatif yaitu MPR, DPR, DPD dan BPK yang memiliki fungsi pengawasan.

DPR merupakan sebuah lembaga negara yang memiliki kewenangan lebih banyak dalam kekuasaan legislatif diantara tiga lembaga lainnya. UUD 1945 pasal 20 pasca perubahan memberikan kewenangan legislasi atas undangundang yang dimiliki penuh oleh badan legislatif dan presiden hanya melakukan pengesahan atas undang-undang yang telah disepakati pembahasannya oleh DPR dan Presiden, bahkan meskipun presiden tidak mengesahkan dalam waktu 30 hari, rancangan undang- undang tersebut tetap sah sebagai undang- undang.

Pasal 20 A UUD 1945 juga menjelaskan kewenangan yang dimiliki oleh DPR sebagai salah satu pemegang kekuasaan legislatif yaitu fungsi legislasi, fungsi anggaran dan fungsi pengawasan. Meski lembaga negara ini memiliki kewenangan dalam hal legislasi peraturan yang sangat besar, akan tetapi terdapat pembatasan secara tidak langsung yang diberikan dalam pembuatan undang-undang tersebut yaitu tidak boleh bertentangan dengan konstitusi atau UUD 1945 dan pengujian atas UU terhadap UUD 1945 merupakan kewenangan Mahkamah Konstitusi yang berada dalam ranah yudikatif sebagai lembaga negara yang merdeka dan bebas dalam menyelenggarakan peradilan, sementara pengujian peraturan dibawah UU yang diuji atas UU diselenggarakan oleh Mahkamah Agung.

Penulis menilai terdapat dua konsep yang hampir sama antara negara Indonesia dengan negara Islam Khilafah dalam pelaksanaan kekuasaan legislasinya. Pertama, kekuasaan legislasi ini dibatasi oleh hal yang bersifat fundamental dalam kedua negara tersebut. Indonesia dibatasi dengan UUD1945 yang merupakan dasar negara yang tidak boleh dilanggar, sementara negara Khilafah dibatasi oleh syara' yang juga merupakan hal fundamental dalam Islam. Kedua, Pada ranah pengawasan. pembuatan UU di Indonesia dapat diujikan kepada lembaga kekuasaan yudikatif, yaitu Mahkmah Konstitusi, agar tidak bertentangan dengan UUD 1945, sedangkan Pengawasan dalam negara Khilafah diuji metode ijtihadnya oleh mahkamah madzalim sebagai pelaksana 
kekuasaan yudikatif. Perbedaan keduanya terdapat pada kekuasaan legislasi yang dijalankan oleh lembaga yang juga menjalankan kekuasaan eksekutif didalam negara Khilafah sedangkan di Indonesia kekuasaan legislasi hanya dijalankan oleh lembaga yang tidak memiliki kekuasaan dalam kekuasaan lain.

Indonesia dalam konstitusinya pernah memberikan kekuasaan legislasi kepada presiden yang merupakan pemegang kekuasaan eksekutif juga. Hal ini dapat dilihat dari UUD 1945 sebelum perubahan yang menyatakan bahwa "presiden memegang kekuasaan membentuk undang- undang dengan persetujuan DPR". ${ }^{30}$ Hal ini kemudian membuat kepemimpinan orde baru melakukan banyak sekali tindakan abuse of power dalam membuat undangundang yang kemudian menyebabkan pemerintahan orde baru menjadi rezim otoriter sehingga memerlukan perubahan- perubahan mendasar dalam negara dan berujung pada reformasi dengan agenda amandemen UUD 1945.

Fakta diatas menunjukkan bahwa dalam rumusan pemisahan kekuasaan legislasi yang dipisahkan dari pelaksana kekuasaan eksekutif merupakan bagian dari pelaksanaan prinsip beragama dalam Islam yaitu keadilan dan kesejahteraan. Prinsip keadilan ini terwujud karena ini merupakan tindakan preventif agar tidak terjadi kedholiman atau abuse of power sementara prinsip kesejahteraan yang akan terwujud adalah tidak terlanggarnya hak-hak rakyat akibat tindakan abuse of power.

Perbedaan dalam hal kekuasaan legislasi ini terjadijuga di dalam pembatasan ketidakbolehan melegislasi aturan yang berbeda dengan peraturan sebelumnya, sementara di Indonesia digunakan asas "lex posterior derogate legi priori" dan "lex specialis derogate legi generale" untuk peraturan selevel seperti undang- undang dengan undang- undang, hal ini menunjukkan adanya kebolehan dalam melegislasi peraturan yang berbeda dengan peraturan sebelumnya, sementara terkait dengan peraturan yang tidak boleh saling bertentangan adalah peraturan yang sifatnya lebih rendah tidak boleh bertentangan dengan peraturan yang lebih tinggi dengan menganut asas "lex superior derogate legi inferior".

Pembuatan peraturan yang bertentangan dengan peraturan lainnya ini terkadang terjadi karena adanya pengkhususanatas sesuatu yang mengharuskan

30 A.M Fatwa, Potret Konstitusi Pasca Amandemen UUD 1945, Cetakan I, (Jakarta : Kompas, 2009), hal. 58. 
adanya perbedaan dalam kebijakan, sehingga mengharuskan adanya peraturan yang terkesan bertentangan dengan peraturan lainnya padahal hal tersebut merupakan pengkhususan atas sesuatu dan menjadikan peraturan yang lama terhapuskan dengan peraturan yang baru.

\begin{tabular}{|c|c|}
\hline Kekuasaan legislasi Indonesia & Kekuasaan legislasi negara Khilafah HT \\
\hline $\begin{array}{l}\text { 1. Dijalankan oleh pelaksana } \\
\text { kekuasaan legislatif yang terpi- } \\
\text { sah dari kekuasaan eksekutif. }\end{array}$ & $\begin{array}{ll}1 . & \text { Dilaksanakan oleh pelaksana } \\
\text { kekuasaan yang tidak terpisah } \\
\text { sebagai pelaksana kekuasaan ek- } \\
\text { sekutif. }\end{array}$ \\
\hline $\begin{array}{l}\text { 2. Legislasi tidak boleh bertentan- } \\
\text { gan dengan UUD } 1945 \text { dan dap- } \\
\text { at di judicial review di Mahkamah } \\
\text { Konstitusi }\end{array}$ & \begin{tabular}{|l} 
2. Legislasi tidak boleh bertentangan \\
dengan syara' dan dapat diperma- \\
sahkan metode ijtihadnya di Mah- \\
kamah Madzalim.
\end{tabular} \\
\hline $\begin{array}{l}\text { 3. Boleh bertentangan dengan Per- } \\
\text { aturan yang selevel, tetapi tidak } \\
\text { boleh bertentangan dengan per- } \\
\text { aturan diatasnya. }\end{array}$ & $\begin{array}{ll}\text { 3. } & \text { Tidak membolehkan adanya pera- } \\
\text { turan yang bertentangan dengan } \\
\text { peraturan sebelumnya }\end{array}$ \\
\hline
\end{tabular}

Fungsi Pengawasan yang dimiliki oleh majelis al-ummah juga memiliki perbedaan yang sangat fundamental dengan pengawasan yang dimiliki oleh lembaga legislatif di Indonesia. Lembaga legislatif di Indonesia tidak dapat secara langsung memecat pelaksana kekuasaan ekskutif sebelum adanya putusan dari lembaga yudikatif. Lembaga legislatif hanya memiliki hak untuk mengusulkan kepada presiden melalui menteri dalam negeri atas putusan mahkamah agung terhadap tindakan kepala daerah yang tidak memenuhi syarat atau melanggar sumpah sebagai kepala daerah sebagaimana tercantum dalam undang-undang. ${ }^{31}$ Pengaturan ini merupakan implikasi dari adanya pemilihan kepala daerah yang dipilih secara langsung oleh rakyat.

Konsekuensi adanya pemilihan langsung kepada pelaksana eksekutif ini membuat pejabat legislatif tidak memiliki kewenangan untuk memecat anggota eksekutif di Indonesia, sehingga keputusannya digantungkan terhadap pengadilan atau kekuasaan yudikatif yang bersifat independen. Hal ini berbeda

31 UU No. 32 tahun 2004 pasal 42 huruf (d) berbunyi DPRD memiliki tugas dan wewenang mengusulkan pengangkatan dan pemberhentian kepala daerah atau wakil kepala daerah kepada presiden melalui menteri dalam negeri bagi DPRD Provinsi dan Kepada menteri dalam negeri melalui gubernur bagi DPRD Kabupaten/Kota. 
dengan negara Khilafah yang pemilihan para wali sebagai penguasa daerah ditunjuk langsung oleh khalifah, akan tetapi beliau dapat dijatuhkan oleh majelis al-ummah yang keputusannya dalam menilai seorang wali mengikat Khalifah untuk memecat para wali yang menjabat di daerah.

Pemecatan pejabat eksekutif atas hasil keputusan legislatif ini pernah dilakukan pada zaman orde baru. Kewenangan lembaga legislatif ini dikarenakan adanya pemilihan kepala daerah yang dilakukan oleh lembaga legislatif sebagai manifestasi dari rakyat, akan tetapi prosedur semacam ini kemudian dihapuskan dalam penyelenggaraan tata negara Indonesia dikarenakan banyak penyalahgunaan kekuasaan yang dilakukan lembaga eksekutif dalam menyandera pejabat eksekutif terutama dalam hal laporan pertanggungjawaban.

Dua perbedaan mendasar dalam negara Khilafah Hizbut Tahrir atas negara Indonesia ini pada dasarnya merupakan bentuk dari sistem yang pernah diterapkan di Indonesia yang kemudian dinilai tidak baik dan dihapuskan. Oleh karena itu, penulis menilai bahwa dalam konstruksi negara Khilafah masih perlu diperbaiki kembali atau direkonstruksi untuk dapat diterapkan di Indonesia terkait dengan kekuasaan dalam bidang legislatifnya.

\section{Analisis Penerapan Konsep Kekuasaan Yudikatif Negara Islam Khilafah Hizbut Tahrir di Indonesia.}

Kekuasaan Yudikatif merupakan kekuasaan yang dirumuskan oleh Montesquieu dalam trias politika. Montesquieu berpendapat bahwa kekuasaan peradilan atau kehakiman merupakan kekuasaan yang harus dipisahkan sendiri dan tidak bisa dimasukkan ke dalam kekuasaan eksekutif sebagaimana yang dikonsepkan oleh john locke. ${ }^{32}$ Mahfud M. D menyatakan bahwa kekuasaan kehakiman merupakan kekuasaan untuk memeriksa dan mengadili serta memberikan putusan-putusan atas perkara yang diserahkan kepadanya. ${ }^{33}$

Kekuasaan kehakiman memiliki fungsi untuk melakukan kontrol terhadap kekuasaan negara dikarenakan adanya intrumentasi hukum yang menjadi

32 Miriam Budiardjo, Dasar-dasar ..., op. cit., hal. 283.

33 Romi Libriyanto, Trias Politica dalam Struktur Ketatanegaraan Indonesia, Cetakan I, (Makassar : PuKAP Indonesia, 2008), hal.77. 
bagian dari kekuasaan. ${ }^{34}$ Pada dasarnya kekuasaan kehakiman ini merupakan kekuasaan yang harus mandiri dan terlepas dari pengaruh kekuasaan pemerintah. Hal ini dikarenakan apabila kekuasaan yudisial tidak mandiri atau dapat dipengaruhi oleh kekuasaan pemerintah atau eksekutif maupun legislatif, maka hukum yang berada dalam sebuah negara tersebut tidak akan dapat berjalan sebagaimana mestinya.

Kekuasaan kehakiman dalam negara Khilafah Hizbut Tahrir berada dalam naungan al-Qadhi. Al-Qadhi merupakan lembaga yang mengurusi dalam bidang penegakan hukum. Secara fungsi, al- Qadhi hampir sama dengan kekuasaan kehakiman yang berada di Indonesia, meskipun terdapat beberapa hal yang berbeda. Negara Khilafah sama sekali tidak membagi peradilan sebagaimana di Indonesia, Peradilan di Negara Khilafah hanya dibagi menurut perkara yang ada untuk dihakimi oleh seorang hakim yang secara jabatan berbeda.

Berkaitan dengan kekuasaan yudikatif dalam negara Khilafah, Lembaga alQadhi ini secara posisi dalam struktur daulah Islam Khilafah Hizbut Tahrir berada di bawah khalifah. Posisi ini menyebabkan adanya kekuasaan yang berada diatas lembaga al- Qadhi yang secara das sein haruslah bersifat mandiri menjadi tidak mandiri. Khalifah dalam kekuasaan yudikatif memiliki wewenang untuk mengangkat seorang hakim qudhat yang merupakan ketua dari para qadhi dan memiliki wewenang untuk mengangkat para qadhi sebagaimana disebutkan dalam pasal 76 Rancangan Undang- undang Dasar negara Khilafah. ${ }^{35}$

Struktur posisi Qodhi dalam struktur negara Khilafah Hizbut Tahrir dapat dilihat dibawah ini.

${ }^{34}$ Ibid, hal. 76.

35 Pasal 76 : Khalifah mengangkat Qadhi qudlat yang berasal dari kalangan laki- laki, baligh, merdeka, muslim, berakal, adil dan faqih. Jika khalifah memberinya wewenang untuk mengangkat dan memberhentikan qadhi madzalim, maka qadhi qudhat wajib seorang mujtahid.Qadhi qudhat memiliki wewenang mengangkat para qadhi, memberi peringatan dan memberhentikan mereka dari jabatannya, sesuai dengan peraturan administratif yang berlaku. Pegawai- pegawai peradilan terikat dengan kepala kantor peradilan yang mengatur urusan administrasi untuk lembaga peradilan. 


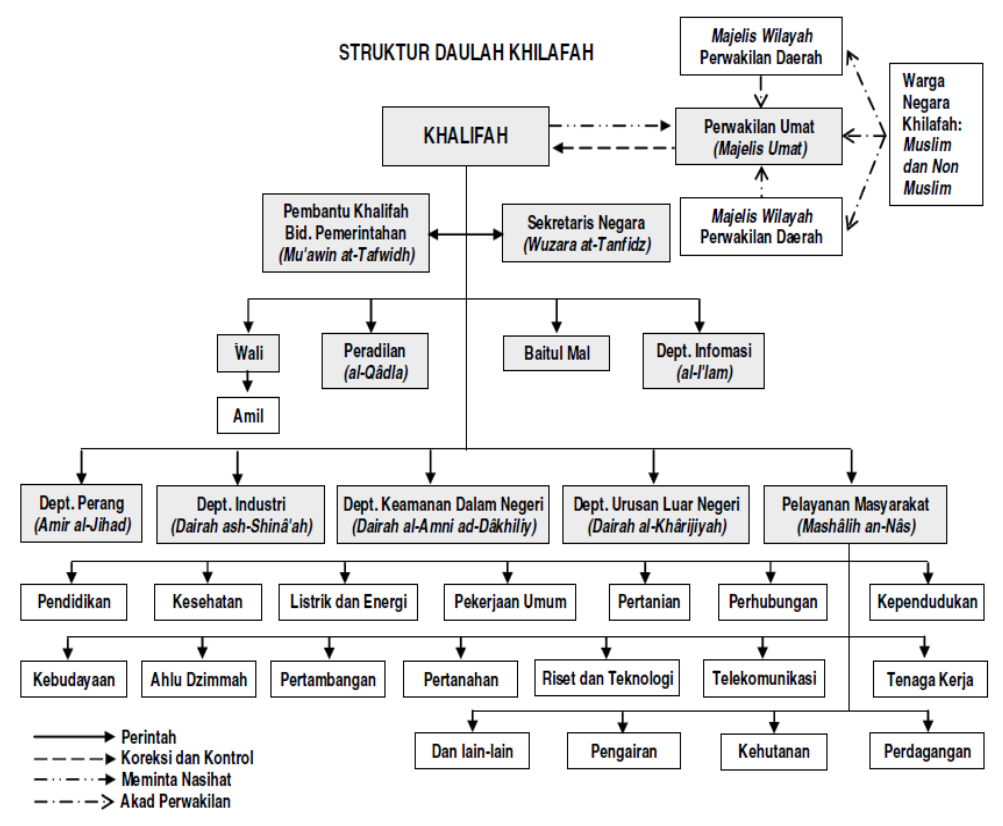

Khalifah sebagai lembaga negara yang berada diatas lembaga al-Qadhi ini juga dapat mengangkat seorang qadhi madzalim yang mengurusi permasalahan perselisihan yang terjadi antara rakyat dengan negara apabila wewenang pengangkatan dan penetapan tersebut tidak diberikan kepada qadhi qudhat sebagai kepala dari para qadhi. Hal ini dapat dilihat dalam pasal 88 undangundang dasar negara Khilafah dibawah ini.

\section{Pasal 88}

Qadhi Madzalim ditetapkan dan diangkat oleh khalifah atau oleh qadhi qudhat.Koreksi, Pemberian peringatan dan pemberhentianya dilakukan oleh khalifah, atau qadhi qudhat jika khalifah memberikan wewenang kepadanya-.Pemberhentian tidak dapat dilakukan terhadap qadhi madzalim yang tengah memeriksa perkara (antara rakyat dengan) khalifah, atau dengan Muawwin Tafwidh atau dengan qadhi qudhat. Wewenang memberhentikan qadhi madzalim dalam kondisi itu berada di tangan mahkamah madzalim. ${ }^{36}$

36 Taqiyyuddin an-Nabhani, Daulah Islam..., op. cit, hal. 315- 316. 
Permasalahan utama dalam kekuasaan yudikatif negara Islam Hizbut Tahrir ini, menurut penulis, terletak pada adanya lembaga yang berada diatas Al-Qadhi sebagai pelaksana kekuasaan yudikatif. Hal ini kemudian berimplikasi terhadap dua hal yang menurut penulis akan dapat menimbulkan kesempatan untuk melakukan tindakan abuse of power dalam pelaksanaan penyelenggaraan pemerintahan dalam negara Khilafah.

Pertama, Khalifah memiliki kekuasaan untuk mengangkat qadhi qudhat dan seluruh qadhi, dalam hal menentukan dan memberhentikan, sementara pengangkatan dilakukan oleh qadhi qudhat. ${ }^{37}$ Kewenangan ini mengindikasikan bahwa kekuasaan yudikatif berjalan dibawah khalifah yang merupakan pelaksana kekuasaan eksekutif. Selain itu, Jabatan qadhi qudhat yang diberikan secara langsung oleh khalifah ini dapat menyebabkan tindakan abuse of power yang dilakukan oleh qadhi qudhat dalam putusan atau pemilihan para qadhi yang menyangkut orang- orang disekitar khalifah.

Kedua, penetapan dan pengangkatan qadhi madzalim dilakukan oleh khalifah atau bisa diberikan kewenangannya oleh qadhi qudhat dengan catatan qadhi qudhat seorang mujtahid. Kewenangan ini sangatlah rawan penyalahgunaan kekuasaan. Qadhi madzalim merupakan qadhi yang mengadili permasalahan antara rakyat dan negara, hal ini berarti seorang qadhi madzalim akan memutuskan perkara yang menyangkut dengan khalifah dan aparatur negara, akan tetapi pengangkatannya dilakukan oleh orang yang permasalahannya diselesaikan oleh qadhi madzalim ini, bahkan khalifah juga dapat melakukan koreksi, pemberian peringatan dan pemberhentian jabatan qadhi madzalim.

Dua permasalahan diatas ini merupakan permasalahan yang tidak ditemui dalam kekuasaan yudikatif di Indonesia. Penentuan jabatan tertinggi dalam kekuasaan yudikatif yang didalamnya dibagi kepada dua lembaga utama yaitu Mahkamah Agung dan Mahkamah Konstitusi serta lembaga pelengkap yaitu Komisi Yudisial. Hakim agung yang merupkan jabatan tertinggi dalam lembaga Mahkamah Agung memiliki pola dalam pemilihan anggota hakim agung yang melibatkan komisi yudisial dan Dewan Perwakilan Rakyat dan kemudian diangkat oleh Presiden.

37 Kewenangan khalifah ini bisa dilihat dalam pasal 36 yang mengatur tentang kewenangan khalifah yang pada huruf e dijelaskan bahwa khalifah memiliki kewenangan untuk menentukan dan memberhentiakan Qadhi qudhat dan seluruh qadhi. 
Prosedural untuk menentukan seseorang dapat menduduki jabatan sebagai hakim agung dilakukan dengan adanya proses seleksi oleh Komisi Yudisial, setelah itu dari 3 calon yang diberikan oleh Komisi Yudisial akan dilakukan fit and proper test di DPR yang menentukan 1 dari masing-masing tiga perwakilan yang diajukan, setelah keluar nama dari DPR. Presiden akan melantik calon yang lolos seleksi tersebut sebagai hakim agung, selanjutnya untuk penentuan ketua Mahkamah Agung, Hal tersebut dilakukan oleh para hakim agung sebagaimana yang tertuang dalam Surat Keputusan tentang tata tertib pemilihan ketua Mahkamah Agung pasal 1 sebagaimana kutipan dibawah ini.

\section{BAB I}

Ketentuan Umum

\section{Pasal 1}

(1) Pemilihan Ketua Mahkamah Agung dilaksanakan secara langsung, bebas dan rahasia;

(2) Ketua Mahkamah Agung dipilih dari dan oleh Hakim Agung $^{38}$

Pemilihan ketua Mahkamah Konstitusi sebagai pelaksana kekuasaan yudikatif juga sama dengan yang dilakukan didalam Mahkamah Agung bahwa yang memilih dan menentukan ketua Mahkamah Konstitusi adalah dari seluruh Hakim Mahkamah Konstitusi yang beranggotakan 9 orang yang diajukan masing- masing tiga (3) orang oleh DPR sebagai kekuasaan legislatif, Presiden sebagai pelaksana kekuasaan eksekutif dan oleh Mahkamah Agung sebagai pelaksana kekuasaan Yudikatif dan kemudian ditetapkan dengan keputusan presiden. ${ }^{39}$

Peraturan Mahkamah Konstitusi No. 3 Tahun 2012 menyebutkan bahwa Ketua Mahkamah Konstitusi dipilih dari dan oleh hakim mahkamah konstitusi. ${ }^{40}$ Hal ini menunjukkan adanya independensi dalam Mahkamah Konstitusi dari

38 Surat Keputusan Ketua Mahkamah Agung Republik Indonesia No. 19/ KMA/ SK/ II/ 2012 tentang Peraturan Tata Tertib Pemilihan Ketua Mahkamah Agung.

39 Ni'matul Huda, Lembaga Negara dalam Masa Transisi Demokrasi, Ctk. Pertama, (Yogyakarta : UII press, 2007). hal. 139.

40 Peraturan Mahmakah Konstitusi nomor 3 tahun 2012 pasal 2 ayat (1). 
adanya campur tangan para pelaku kekuasaan yudikatif maupun eksekutif agar tidak terjadi penyimpangan atau penyalahgunanaan kekuasaan pada seluruh proses pelaksanaan kekuasaan yudikatif yang dijalankan oleh Mahkamah Konstitusi.

Indonesia dalam pelakasanaan kekuasaan kehakiman pernah memiliki sebuah fase yang buruk sebelum adanya perubahan UUD 1945. Kekuasaan yudikatif pernah mengalami penyelewengan terhadap asas kebebasannya pada masa demokrasi terpimpin dengan dikeluarkannya Undang-undang No. 19 tahun 1964 tentang ketentuan pokok kekuasaan kehakiman pada pasal 19 yang berbunyi " Demi kepentingan revolusi, kehormatan negara dan bangsa atau kepentingan masyarakat yang mendesak, Presiden dapat turut atau campur tangan dalam soal pengadilan". Hal ini kemudian dikembalikan pada tahun 1966 dengan ketetapan MPRS tentang peninjauan kembali terhadap produk legislasi negara yang bertentangan dengan UUD 1945 sehingga pada tahun 1970 dikeluarkanlah UU No. 14 Tahun 1970 yang didalamnya menyatakan independensi kekuasaan kehakiman pada pasal 4 ayat (3) yang berbunyi "segala campur tangan dalam urusan peradilan oleh pihak- pihak lain di luar kekuasaan kehakiman dilarang, kecuali hal-hal yang tersebut dalam Undang Undang Dasar". ${ }^{41}$

Pada masa demokrasi terpimpin juga terjadi adanya rangkap jabatan yang dimiliki oleh ketua mahkamah agung. Ketua mahkamah agung memiliki jabatan dan status sebagai menteri yang diberikan kepadanya, dengan demikian jabatan ketua mahkamah agung sebagai pelaksana kekuasaan yudikatif yang sebenarnya merupakan jabatan yang seharusnya independen dan terpisah dari kekuasaan eksekutif justru menjadi bagian dari pelaksana kekuasaan eksekutif. Keadaan seperti ini kemudian dikoreksi pada zaman orde baru bahwa ketua Mahkamah Agung tidak lagi menjadi menteri atau pembantu presiden. ${ }^{42}$

UU No. 14 Tahun 1970, yang dianggap memerdekaan kekuasaan kehakiman dari intervensi presiden, memiliki kelemahan yang menjadikan kekuasaan kehakiman tidak dapat dijalankan dengan merdeka. Undang-undang ini tetap mempertahankan dualisme kekuasaan kehakiman dengan memberikan pembinaan organisasi, administrasi dan keuangan oleh departemen kehakiman, sementara Mahkamah Agung mengurusi pembinaan teknis peradilan. ${ }^{43} \mathrm{Hal}$ ini

\footnotetext{
41 Miriam Budiardjo, Dasar-dasar ..., op. cit., hal. 358.

42 Ibid, hal. 358.

43 Muhammad Syafi'ie, Dependensi Kekuasaan kehakiman di Era Orde baru dan Hak Keadilan
} 
menyebabkan kekuasaan yudikatif pada saat itu masih tidak bisa independen pelaksanaannya yang berimbas pada putusan hakim yang mendapatkan tekanan atau intervensi dari kekuasaan eksekutif. ${ }^{44}$

Penelitian yang dilakukan oleh Mahkamah Agung, dalam buku cetak biru pengadilan, terkait jaminan Independensi dalam kekuasaan yudikatif sebenarnya sudah tersurat dalam konstitusi Indonesia, akan tetapi hal tersebut tidak dapat di wujudkan pada zaman orde lama dan orde baru dikarenakan pada zaman orde baru terdapat rangkap jabatan terhadap ketua Mahkamah Agung yang sekaligus dijadikan menteri, sementara pada masa orde baru, pemerintah selalu menekan Mahkamah Agung untuk memutuskan perkara sebagaimana yang diinginkan pemerintah. ${ }^{45}$

Kondisi ini menjadikan Indonesia berbenah pada pasca reformasi melalui Undang-Undang Nomor 35 Tahun 1999 sebagai perubahan atas UU No. 14 Tahun 1970 tentang Pokok-pokok Kekuasaan Kehakiman. Salah satu poin penting dalam UU tersebut adalah kebijakan penyatuatapan lembaga peradilan atau yang lebih populer dengan istilah kebijakan satu atap (one roof system) dimana segala urusan peradilan baik yang menyangkut teknis yustisial maupun non yustisial (organisasi, administrasi dan finansial) berada satu atap di bawah Mahkamah Agung. Seiring dengan perkembangan situasi dan kondisi UU tersebut kemudian dirubah menjadi UU No. 4 Tahun 2004 dan perubahan terakhir adalah UU No. 48 Tahun 2009 tentang Kekuasaan Kehakiman. ${ }^{46}$

Perjalanan sejarah kekuasaan yudikatif ini tentunya bertujuan untuk menjadikan adanya penyelenggaraan yanglebih baik dalam kekuasaan yudikatif

Perspektif Islam, http:/ / syafiie.blogspot.com/2011/04/dependensi-kekuasaan-kehakimandi-era.html di akses pada tanggal 14 juni 2016.

44 Ahmad Zaenal Fanani, Kekuasaan Kehakiman yang merdeka dan masa depan peradilan Agama (analisis UU No. 48 Tahun 2009 dan UU No. 50 Tahun 2009), http://www.badilag. net/data/ ARTIKEL/KEKUASAAN\%20KEHAKIMAN\%20YANG\%20MERDEKA \% 20 DAN\%20MASA\%20DEPAN\%20PERADILAN\%20AGAMA.pdf. di akses pada tanggal 14 juni 2016, hal: 3

45 Anonim, Cetak Biru Mahkamah Agung, http://www.pembaruanperadilan.net/v2/ content/2011/01/Cetak-Biru-Mahkamah-Agung-Bab-1-6.pdf, diakses pada tanggal 14 juni 2016, hal. 10.

46 Ahmad Zaenal Fanani, Kekuasaan Kehakiman yang merdeka dan masa depan peradilan Agama (analisis UU no 48 tahun 2009 dan UU no 50 tahun 2009), http:// www.badilag.net/data/ARTIKEL/KEKUASAAN\% 20KEHAKIMAN\% 20YANG\% 20 MERDEKA\%20DAN\%20MASA\%20DEPAN\%20PERADILAN\%20AGAMA.pdf. di akses pada tanggal 14 juni 2016, hal: 4. 
agar dapat berjalan sebagaimana mestinya. Perbedaan mendasar ini menjadikan konsep dalam negara Khilafah, terkait dengan penyelenggaraan kekuasaan yudikatif, yang memposisikan al-qadhi atau lembaga pelaksana kekuasaan yudikatif di bawah khalifah tidak mungkin akan dapat diimplementasikan di Indonesia, mengingat Indonesia telah mengalami fase yang buruk terkait dengan dependensi kekuasaan yudikatif yang menyebabkan konsep penyelenggaraanya diubah menjadi independen dari pelaksana kekuasaan negara yang lain, baik itu legislatif maupun eksekutif.

\section{Analisis Penerapan Konsep Kekuasaan Eksekutif Negara Islam Khi- lafah Hizbut Tahrir di Indonesia.}

Kekuasaan eksekutif dijalankan oleh badan eksekutif yang terdiri atas kepala negara seperti raja atau presiden, beserta menteri-menterinya. Badan eksekutif dalam arti luas juga mencakup para para pegawai negeri sipil dan militer. Dalam konsep trias politika, badan eksekutif pada dasarnya hanya melaksanakan kebijaksanaan-kebijaksanaan yang telah ditetapkan oleh badan legislatif serta menyelenggarakan undang-undang yang dibuat oleh badan legislatif, akan tetapi dalam pelaksanaannya, badan eksekutif ruang geraknya sangat luas sekali. ${ }^{47}$

Kekuasaan eksekutif yang dijalankan oleh badann eksekutif ini dirumuskan dalam ilmu politik dengan adanya lima kewenangan yang dimiliki. Pertama, dalam ranah administratif, yaitu kekuasaan untuk melaksanakan undangundang dan peraturan perundangan-undangan dan menyelenggarakan administrasi negara. Kedua, dalam ranah legislatif, yaitu membuat rancangan undang- undang dan membimbingnya dalam badan perwakilan rakyat sampai menjadi undang- undang. Ketiga, dalam ranah keamanan, yaitu kekuasaan untuk mengatur polisi dan angkatan bersenjata, menyelenggarakan perang, pertahanan negara, serta keamanan dalam negeri. Keempat, dalam ranah yudikatif yaitu memberi grasi dan amnesti. Dan yang terakhir, dalam ranah diplomatik, yaitu kekuasaan untuk menyelenggarakan hubungan diplomatik dengan negara lain. ${ }^{48}$

Konsep pembagian kekuasaan negara Islam Khilafah Hizbut Tahrir, sebagaimana dijelaskan dalam bab II, memberikan kekuasaan yang banyak

47 Miriam Budiardjo, Dasar-dasar ..., op. cit., hal. 295.

48 Ibid, hal. 296-297. 
terhadap khalifah sebagai kepala negara dan kepala pemerintahan. Kekuasaan yang dimiliki oleh seorang khalifah meliputi 6 (enam) hal kewenangan sebagaimana tercantum dalam rancangan undang- undang dasar negara Khilafah pasal 36 yang berbunyi:

\section{Pasal 36}

Khalifah memiliki wewenang sebagai berikut:

a. dialah yang melegislasi hukum-hukum syara' yang diperlukan untuk memelihara urusan umat, yang digali dengan ijtihad yang sahih dari kitabullah dan sunah Rasul-Nya, sehingga menjadi perundang-undangan yang wajib ditaati dan tidak boleh dilanggar;

b. dialah yang bertanggung jawab terhadap politik negeri, baik dalam maupun luar negeri. Dialah yang memegang kepemimpinan militer. Dia berhak mengumumkan perang, mengikat perjanjian damai, gencatan senjata serta seluruh perjanjian lainnya;

c. dialah yang berhak menerima atau menolak dutaduta negara asing. Dia juga berhak menentukan dan memberhentikan duta kaum muslim;

d. dialah yang menentukan dan memberhentikan para muawwin dan para wali dan mereka semua bertanggung jawab kepada khalifah sebagaimana mereka juga bertanggungjawab kepada majelis ummah;

e. dialah yang menentukan dan memberhentikan Qadhi Qudhat, dan seluruh Qadhi kecuali Qadhi Madzalim dalam kondisi qadhi mazhalim sedang memeriksa perkara atas khalifah, muawwin dan qadhi qudhat. Khalifahlah yang berhak menentukan dan memberhentikan para kepala direktorat, komandan militer, dan para pemimpin brigade militer. Mereka bertanggung jawab kepada khalifah dan tidak bertanggung jawab kepada majelis al-ummah;

f. dialah yang menentukan hukum- hukum syara' yang berhubungan dengan anggaran pendapatan dan belanja negara. Dia pula yang menentukan rincian nilai APBN, pemasukan maupun pengeluarannya. ${ }^{49}$

49 Taqiyyudin an-Nabhani, Daulah Islam ..., op. cit., hal. 302- 303. 
Kekuasaan Khalifah pada huruf (a), (e) dan (f) telah dijelaskan pada pembahasan sebelumnya bahwa kewenangan ini seharusnya masuk dalam ranah kekuasaan diluar eksekutif, untuk huruf (a) dan (f) masuk dalam ranah legislatif dan huruf (e) masuk dalam ranah yudikatif. Sementara dalam huruf (b) merupakan kewenangan yang memang harus dimiliki oleh pelaksana kekuasaan eksekutif dalam pengertian luas sebagaimana dijelaskan dalam ilmu politik terkait dengan kekuasaan eksekutif dalam arti luas.

Pada pasal 36 huruf (c) menjelaskan bahwa kekuasaan dalam menerima dan menolak duta asing atau memberhentikan duta kaum muslimin juga masuk dalam ranah kekuasaan badan eksekutif pada dasarnya, namun hal ini berbeda dengan konsep yang diatur dalam negara Indonesia yang memberikan aspek perimbangan antara kekuasaan eksekutif dengan kekuasaan legislatif dalam pelaksanaan pasal ini sebagaimana yang tercantum dalam pasal 13 UUD 1945 yang berbunyi:

\section{Pasal 13}

(1) Presiden mengangkat duta dan konsul;

(2) dalam hal mengangkat duta, presiden memperhatikan pertimbangan Dewan Perwakilan Rakyat;

(3) Presiden menerima penempatan duta negara lain dengan memperhatikan pertimbangan Dewan Perwakilan Rakyat;,50

Pada masa sebelum reformasi, Presiden sebagai kepala negara memiliki kewenangan untuk menentukan sendiri duta dan konsul serta menerima duta negara lain. Mengingat pentingnya hal tersebut, maka Presiden dalam mengangkat dan menerima duta besar sebaiknya diberikan pertimbangan oleh Dewan Perwakilan Rakyat untuk menjaga obyektivitas terhadap kemampuan dan kecakapan seseorang yang menempati posisi tersebut. ${ }^{51} \mathrm{Hal}$ ini dikarenakan perwakilan tersebut akan menjaga nama baik negara dimata internasional dan demi terjalinnya kerjasama yang baik antar kedua bangsa dan negara. ${ }^{52}$

Kewenangan dalam posisi penempatan dan penerimaan duta besar yang mutlak diberikan kepada khalifah ini ternyata memiliki celah untuk

50 Undang Undang Dasar Republik Indonesia 1945.

51 Dulu pada masa orde baru jabatan duta merupakan jabatan pos akomodasi untuk orang-orang tertentu yang dianggap berjasa pada pemerintah atau sebagai tempat pengasingan bagi orang-orang yang kurang loyal terhadap pemerintah.

52 Ni'matul Huda, Lembaga Negara ..., op. cit., hal. 124. 
disalahgunakan dan hal tersebut pernah terjadi di Indonesia, hal ini bermakna kewenangan khalifah dalam melakukan penempatan dan penerimaan duta ini tidak bisa diberikan kepada khalifah secara mutlak sebagai pelaksana kekuasaan eksekutif apabila ingin diterapkan di Indonesia.

Kewenangan terakhir yang belum dibahas dalam kekuasaan eksekutif adalah kewenangan untuk menentukan para muawwin dan para wali. Pada dasarnya, kewenangan dalam pelaksanaan kekuasaan eksekutif memang dijalankan oleh seorang presiden beserta menteri- menterinya dan pelaksana eksekutif di daerah dan pelaksanaan yang dijalankan didaerah pada dasarnya merupakan kepanjangan tangan dari pelaksanaan yang dijalankan di tingkat pusat. Negara Islam Khilafah memberikan kewenangan ini terhadap khalifah menurut penulis dikarenakan Khalifah merupakan seseorang yang dipilih oleh umat, sehingga khalifah sendiri merupakan manifestasi dari rakyat sebagaimana telah dijelaskan dalam empat pilar negara bahwa kekuasaan di tangan umat terbatas pada pemilihan seorang khalifah sebagai orang yang diberikan kepercayaan oleh umat.

Khalifah yang dipilih oleh umat ini kemudian menentukan para muawwin dan para wali dalam pelaksanaan pemerintahannya. Kelebihan dari sistem ini adalah para muawwin dan para wali yang berada didaerah merupakan orang yang loyal kepada khalifah dan memudahkan khalifah dalam menjalankan penyelenggaraan pemerintah, akan tetapi sistem ini bukan tanpa kelemahan, kelemahan dari sistem ini adalah jika posisi-posisi tersebut digunakan untuk memperkuat kekuasaan seorang khalifah dan orang-orang dekatnya, maka negara ini akan menjadi negara yang bersifat tirani.

Indonesia Pasca reformasi memberikan ketentuan pada pemilihan gubernur dengan dilakukan pemilihan umum secara langsung. Rakyat diberikan hak secara langsung memilih kepala daerah sesuai dengan yang mereka kehendaki tanpa diwakili oleh siapapun, baik presiden sebagai kepala negara ataupun Dewan Perwakilan Rakyat, baik pusat maupun daerah. Hal ini didasarkan pada pemaknaan pasal 18 ayat (4) UUD 1945 yang menyatakan bahwa gubernur, bupati dan walikota masing- masing sebagai kepala daerah provinsi, kabupaten dan kota dipilih secara demokratis. ${ }^{53}$

53 Undang-undang Dasar 1945. 
Pengaturan terkait dengan kepala daerah harus dipilih secara langsung di Indonesia bukan tanpa perjalanan panjang, Indonesia pernah melakukan pengaturan yang berbeda dengan pengaturan seperti yang dilakukan sekarang ini dan menimbulkan sebuah permasalahan yang terjadi, sehingga konsep pemilihan langsung kepala daerah yang diterapkan saat ini merupakan pilihan terbaik yang ada meskipun menurut beberapa pengamat tata negara dan politik juga memiliki kelemahan dalam pelaksanannya. ${ }^{54}$

Pada masa orde baru, Mekanisme pemilihan kepala daerah dalam Undangundang Nomor 5 Tahun 1974 mengatur bahwa Kepala Daerah Tingkat I dicalonkan dan dipilih oleh Dewan Perwakilan Rakyat Daerah dari sedikitdikitnya 3 (tiga) orang dan sebanyak-banyaknya 5 (lima) orang calon yang telah dimusyawarahkan dan disepakati bersama antara pimpinan Dewan Perwakilan Rakyat Daerah/ pimpinan fraksi-fraksi dengan Menteri Dalam Negeri. Hasil pemilihan tersebut diajukan oleh Dewan Perwakilan Rakyat Daerah yang bersangkutan kepada Presiden melalui Menteri Dalam Negeri sedikit-dikitnya 2 (dua) orang untuk diangkat salah seorang di antaranya. Kepala Daerah tingkat II dicalonkan dan dipilih oleh Dewan Perwakilan Rakyat Daerah dari sedikitdikitnya 3 (tiga) orang dan sebanyak-banyaknya 5 (lima) orang calon yang telah dimusyawarahkan dan disepakati bersama antara pimpinan Dewan Perwakilan Rakyat Daerah/pimpinan Fraksi-fraksi dengan Gubernur kepala daerah. ${ }^{55}$

Sentralisasi politik orde baru yang dituangkan dalam Undang-undang Nomor 5 Tahun 1974 tentang Pemerintahan Daerah ini hanya menjadikan pemerintahan daerah sebagai perpanjangan tangan pemerintah pusat belaka. Hal ini terlihat pada pembuatan peraturan daerahyang tidak jarang pemerintah pusat melalui kementerian dalam negeri mementahkan kembali aspirasi masyarakat di daerah menyangkut persoalan pembagian sumber daya alam

${ }^{54}$ Kelemahan dalam sistem pemilihan kepala daerah secara langsung adalah adanya biaya pilkada yang tinggi, Mendagri Gamawan Fauzi menyatakan bahwa gaji gubernur hanya 8,7 perbulan sementara menjadi seorang gubernur dibutuhkan 20 Milyar rupiah (kompas, 23 Juli 2010), lihat juga dalam tulisan A. Hakim Naja, Menekan biaya tinggi dalam Pilkada, http://www.google.com/url?sa=t\&rct=j\&q=besarnya\%20biaya \%20pilkad a\&source=web\&cd=1\&cad=rja\&ved=0CCYQFjAA\&url=http $\% 3 \mathrm{~A} \% 2 \mathrm{~F} \% 2 \mathrm{Fwww}$.perludem. or.id\%2Findex.php\%3Foption\%3Dcom_k2\%26view\%3Ditem\%26task\%3Ddownload\%26id \%3D150_ce66890a06187d2ca5d5a869db1e3779\&ei=eia9UZHUIYaRrAeIhIDoDA\&usg=AF QjCNFQC-e5-9m-WGljL0Npg9IVNyPxvw\&bvm=bv.47883778,d.bmk, diakses pada tanggal 16 Juni 2016.

55 Pasal 15 Undang-Undang Nomor 5 Tahun 1974. 
yang tidak mencerminkan keadilan antara pemerintah pusat dan daerah, sehingga prinsip keadilan dan kesejahteraan di daerah menjadi hal yang sangat sulit terwujud dalam pelaksanaannya. ${ }^{56}$

Permasalahan diatas menjadikan Indonesia melakukan pengaturan ulang tentang pemilihan kepala daerah yang dilakukan secara langsung oleh masyarakat agar pelaksana eksekutif di daerah selain benar-benar mengetahui kondisi di daerah juga memiliki daya tawar sebagai perwakilan masyarakat didaerah terkait dengan kepentingan daerah dan tidak ada politisasi pusat didaerah yang banyak menolak aspirasi masyarakat dan mementingkan kepentingan pusat secara dominan dalam permasalahan yang menyangkut antara daerah dan pusat.

Kekuasaan eksekutif yang diatur dalam rancangan undang- undang dasar negara Khilafah masih banyak yang harus diperbaiki terkait dengan kewenangan khalifah dalam menjalankan kekuasaan eksekutif yang dimiliki agar dapat diterapkan di Indonesia. Selain dari kewenangan kekuasaan eksekutif yang terlalu besar, penulis merasa bahwa masa jabatan kekuasaan eksekutif dalam negara Khilafah Hizbut Tahrir juga merupakan permasalahan yang harus diperbaiki apabila ingin dapat diterapkan di Indonesia.

Masa jabatan Khalifah sebagai pelaksana kekuasaan eksekutif, dalam negara Khilafah, tidak memiliki batasan. Hal ini dapat dilihat dalam pasal 39 rancangan undang-undang dasar negara Khilafah yang berbunyi.

Pasal 39

Tidak ada batas waktu bagi jabatan khalifah. Selama mampu mempertahankan dan melaksanakan hukum syara', serta mampu menjalankan tugas- tugas negara, ia tetap menjabat sebagai khalifah. Kecuali terdapat perubahan keadaan yang menyebabkannya tidak layak lagi menjabat sebagai khalifah sehingga wajib segera diberhentikan. ${ }^{57}$

Ketiadaan batasan dalam jabatan khalifah ini tentunya akan bermasalah jika akan diterapkan di negara Indonesia, pasalnya Indonesia pernah mengalami

\footnotetext{
56 Anonim, Bab II Pengaturan Tentang Pemilihan Kepala Daerah di Indonesia, http:// repository.usu.ac.id/bitstream/123456789/23588/3/Chapter\%20II.pdf, diakses pada tanggal 16 juni 2016.

57 Taqiyuddin An- Nabhani, Daulah Islam..., op. cit., hal. 304.
} 
fase buruk saat orde baru yang ingin melanggengkan kekuasaan dan terjadi hingga 32 tahun kepemimpinan Presiden Soeharto dengan mendasarkan pada UUD 1945 pasal 7 sebelum perubahan yang berbunyi bahwa Presiden dan wakil presiden memegang jabatannya selam lima tahun dan sesudahnya dapat dipilih kembali. ${ }^{58}$ Pasal ini bahkan sempat ditafsirkan oleh Presiden Soeharto dengan menyatakan bahwa jabatan Presiden hanya dibatasi masa periodenya akan tetapi tidak dibatasi dalam jumlah berapa kali dia menjabat, selama masih dipilih oleh MPR, maka seseorang dapat menjabat sebagai Presiden. ${ }^{59}$

Pasal ini kemudian dirubah pada masa berakhirnya rezim Soeharto dengan alasan bahwa jika masa jabatan presiden tidak dibatasi maka akan timbul kepemimpinan yang otoriter, tindakan abuse of power, regenerasi kepemimpinan nasional yang terhambat dan munculnya pengkultusan individu. Indonesia telah belajar dari masa lalu pada masa kepemimpinan Presiden Soekarno dan Soeharto, Soekarno pernah mengangkat dirinya sendiri menjadi presiden seumur hidup dan Soeharto mencoba mencari celah untuk berkuasa dengan memanfaatkan celah pasal 7 sebelum amandemen tersebut. ${ }^{60}$ M. Fajrul Falakh juga menyatakan bahwa pembatasan ini merupakan salah satu ciri dari sistem presidensial yang mengatur bahwa presiden memiliki masa jabatan yang tetap. ${ }^{61}$

Keadaan ini kemudian membuat Indonesia melakukan perubahan konstitusi saat berakhirnya orde baru dengan memberi batasan terhadap masa jabatan presiden yang hanya bisa dipilih untuk satu periode selanjutnya, dan tidak mungkin menjabat lagi setelah itu. ${ }^{62} \mathrm{Hal}$ ini sangat berbanding terbalik dengan konsep yang ada dalam negara Khilafah Hizbut Tahrir yang tidak membatasi jabatan Khalifah bahkan untuk periodesasinya, sehingga sangat

58 UUD 1945 sebelum perubahan.

59 Ni'matul Huda, Lembaga Negara..., op. cit., hal. 123.

60 Fajar dan Dwi RA, Kenapa Masa Jabatan Presiden Perlu Dibatasi?, http://www.tempo. co/read/news/2010/08/19/078272307/Kenapa-Masa-Jabatan-Presiden-Perlu-Dibatasi diakses pada tanggal 16 juni 2016.

61 Boy Yendra Tamin, Sisi Lain Dari Gagasan Perubahan Periode Jabatan Presiden, http:/ / boyyendratamin.blogspot.com/2011/03/sisi-lain-dari-gagasan-perubahan.html, diakses pada tanggal 16 juni 2016.

${ }^{62}$ Lihat UUD 1945 pasal 7 perubahan pertama. 
memungkinkan sekali bahwa dalam negara Khilafah akan terdapat seorang pemegang kekuasaan eksekutif yang menjabat hingga meninggal dunia.

Ketiadaan pembatasan dalam jabatan khalifah ini, jika menimbulkan permasalahan seperti diatas, tentunya akan sangat bertentangan dengan prinsip bernegara dalam Islam terkait dengan tindakan preventifnya. Tindakan abuse of power, kepemimpinan yang otoriter, pengkultusan individu dan penghambatan regenerasi kepimimpinan sangat bertentangan dengan prinsip bernegara dalam Islam dalam hal prinsip amanah, prinsip persamaan dan hilangnya penegakan keadilan yang seharusnya dijalankan dalam bernegara.

\section{E. Kesimpulan}

Negara Islam Khilafah Hizbut Tahrir merupakan sebuah konsep negara yang di rumuskan oleh kelompok Hizbut Tahrir dan didasarkan pada agama Islam. Konsep negara ini, sebagaimana yang telah dipaparkan oleh penulis pada bab sebelumnya, tidak memiliki konsepsi pembagaian kekuasaan dalam kekuasaan negara. Kekuasaan negara ini lebih banyak diberikan kepada seorang Khalifah yang merupakan manifestasi dari umat atau masyarakat.

Khalifah sebagai kepala negara dan kepala pemerintahan memiliki kekuasaan yang sangat besar. Wewenang Khalifah sebagai pelaksana kekuasaan eksekutif juga mencakup dalam kekuasaan legislatif yaitu melegislasi hukumhukum syara', sementara majelis al-ummah yang memiliki fungsi representasi umat hanya diberi kekuasaan untuk menasehati atau memberi masukan kepada khalifah. Kewenangan ini bahkan tidak dikontrol oleh sebuah lembaga lain agar tidak terjadi proses penyimpangan dalam pelaksanaannya, sehingga pemberian kekuasaan legislasi yang diberikan dapat mengakibatkan terjadinya tindakan abuse of power yang dilakukan oleh Khalifah.

Kewenangan yang diberikan Khalifah dalam rancangan undang- undang dasar negara Khilafah juga mencakup kekuasaan yang diberikan secara keseluruhan dalam kekuasaan yudikatif. Hal ini dapat dilihat dari posisi Khalifah yang berada diatas Al-Qadhi, yang merupakan badan atau lembaga pelaksana kekuasaan yudikatif, dan memiliki kewenangan mengangkat dan menentukan para hakim tak terkecuali seorang qadhi (hakim) madzalim yang mengurusi permasalahan antara rakyat dengan negara. 
Konsep Pembagian kekuasaan negara Khilafah ini berbeda dengan konsep pembagian yang ada dalam negara Indonesia, bahkan Indonesia memiliki sejarah yang mengharuskan Indonesia untuk memperbaiki sistem, terkait dengan kewenangan lembaga eksekutif, legislatif dan yudikatif, menjadi seperti yang sekarang ini tercantum dalam UUD 1945 saat ini dan konsep yang dimiliki oleh Hizbut Tahrir tersebut sebagian besar merupakan sebuah sistem yang pernah terjadi di Indonesia dan mengharuskan untuk dirubah karena menimbulkan permasalahan dalam pelaksanaanya. Oleh karena itu, konsepsi pembagian kekuasaan yang dimiliki dalam konsep negara Islam Khilafah Hizbut Tahrir tidak akan dapat diterapkan dalam negara Indonesia, meskipun pada dasarnya mereka mendasarkan konsep negaranya kepada agama Islam yang merupakan agama yang dipeluk oleh mayoritas penduduk Indonesia.

\section{DAFTAR PUSTAKA}

\section{Buku-Buku}

Al-amin, Ainur Rofiq. 2012. Membongkar Proyek Khilafah ala Hizbut Tahrir di Indonesia, Cetakan II, Yogyakarta : LKiS.

An- Nabhani, Taqiyyuddin. Daulah Islam, terj.Umar Faruq, dkk, Ctk. 4, Jakarta : HTI- Press.

Budiardjo, Miriam . 2008. Dasar-dasar Ilmu Politik, Edisi revisi, Ctk. Pertama, Jakarta : Gramedia.

Fatwa, A.M . 2009. Potret Konstitusi Pasca Amandemen UUD 1945, Cetakan I, Jakarta . Kompas.

Hizbut Tahrir, 2008. Struktur Negara Khalifah (Pemerintahan dan Administrasi), terj. Yahya A.R, Ctk. Ketiga, Jakarta : HTI-Press.

Huda, Ni'matul. 2007. Lembaga Negara dalam Masa Transisi Demokrasi, Ctk. Pertama, Yogyakarta : UII Press.

Jafri, Syed Hussain Mohammad, 2012. Agama dan Negara dalam Pandangan Imam Ali, Cetakan I, Yogyakarta : Rausyanfikr Institute.

Librayanto, Romi. 2008. Trias Politica dalam Struktur Ketatanegaraan Indonesia, Cetakan I, Makassar : PuKAP Indonesia.

Rais, Dhiauddin. 2001. Teori Politik Islam, diterjemahkan oleh Abdul Hayyie alKattani, Andi Aderus Banua,dkk, cetakan I, Jakarta : Gema Insani Press. 
Victoria, Adi. 2012. Khilafah the answer; Catatan Ideologis seputar dakwah dan syari'ah, Cetakan I, Yogyakarta : Kutlah Media.

Wahid, Abdurrahman. 2006. Islamku, Islam Anda Islam Kita; Agama Masyarakat Negara Demokrasi, Cetakan II, Jakarta : The Wahid Institute.

\section{Internet}

Hizbut Tahrir Indonesia, Manifesto Hizbut Tahriruntuk Indonesia(Indonesia, khilafah dan penyatuan kembali dunia Islam) http://hizbut-tahrir.or.id/2007/12/11/ mafahim-hizbut-tahrir/diakses pada tanggal 5 Februari 2013.

Asmaul Husna, Jejak Syari'ah dan Khilafah di Sumatra, http://hizbut-tahrir. or.id/2007/06/12/jejak-syariah-khilafah-di-sumatera/ diakses pada tanggal 5 Februari 2013.

M. Shiddiq Al-Jawi, Empat Pilar Negara Khilafah, http://hizbuttahrir. or.id/2012/06/13/empat-pilar-negara-khilafah/ diakses pada tanggal 5 Februari 2013.

Lajnah Tsaqofiyyah Hizbut Tahrir, Jawaban Tuntas Pertanyaan Berulang Seputar Khilafah dan Hizbut Tahrir, http://hizbut-tahrir.or.id/2012/09/05/ jawaban-tuntas-pertanyaan-berulang-seputar-khilafah-dan-hizbuttahrir/ diakses pada tanggal 5 Februari 2013.

Muhammad Ismail Yusanto, Menjawab Kritikan terhadap Konsep Khilafah http:/ / hizbut-tahrir.or.id/2007/07/10/menjawab-kritikan-terhadap-konsepkhilafah/ diakses pada tanggal 10 Februari 2013.

Muhammad Syafi'ie, Dependensi Kekuasaan kehakiman di Era Orde baru dan Hak Keadilan Perspektif Islam, http://syafiie.blogspot.com/2011/04/ dependensi-kekuasaan-kehakiman-di-era.html di akses pada tanggal 14 juni 2013.

Ahmad Zaenal Fanani, Kekuasaan Kehakiman yang merdeka dan masa depan peradilan Agama (analisis UU no 48 tahun 2009 dan UU no 50 tahun 2009), http://www.badilag.net/data/ARTIKEL/KEKUASAAN $\% 20$ KEHAKIMAN\% 20YANG\% 20MERDEKA \% 20DAN\% 20MASA \% 20 DEPAN\%20PERADILAN\%20AGAMA.pdf. di akses pada tanggal 14 juni 2013, hal: 3

Anonim, Cetak Biru Mahkamah Agung, http://www.pembaruanperadilan.net/ v2/content/2011/01/Cetak-Biru-Mahkamah-Agung-Bab-1-6.pdf, diakses pada tanggal 14 juni 2013, hal. 10. 
Ahmad Zaenal Fanani, Kekuasaan Kehakiman yang merdeka dan masa depan peradilan Agama (analisis UU no 48 tahun 2009 dan UU no 50 tahun 2009), http://www.badilag.net/data/ARTIKEL/KEKUASAAN $\% 20$ KEHAKIMAN\%20YANG\%20MERDEKA \% 20DAN \% 20MASA \% 20 DEPAN\%20PERADILAN\%20AGAMA.pdf. di akses pada tanggal 14 juni 2013, hal: 4 .

A. Hakim Naja, Menekan biaya tinggi dalam Pilkada, http://www.google. $\mathrm{com} /$ url? sa $=$ t\&rct=j\&q=besarnya $\% 20$ biaya $\% 20$ pilkada\&source=we $\mathrm{b} \& \mathrm{~cd}=1 \& \mathrm{cad}=\mathrm{rja} \& \mathrm{ved}=0 \mathrm{CC} Y \mathrm{QFjAA} \& u r l=\mathrm{http} \% 3 \mathrm{~A} \% 2 \mathrm{~F} \% 2 \mathrm{Fwww}$. perludem.or.id\%2Findex.php\%3Foption\%3Dcom_k2\%26view\%3Dit em\%26task\%3Ddownload\%26id\%3D150_ce66890a06187d2ca5d5a86 9db1e3779\&ei=eia9UZHUIYaRrAeIhIDoDA\&usg=AFQjCNFQC-e59m-WGljL0Npg9IVNyPxvw\&bvm=bv.47883778,d.bmk, diakses pada tanggal 16 Juni 2013.

Anonim, Bab II Pengaturan Tentang Pemilihan Kepala Daerah di Indonesia, http:/ / repository.usu.ac.id/bitstream/123456789/23588/3/Chapter\%20II. pdf, diakses pada tanggal 16 juni 2013.

Fajar dan Dwi RA, Kenapa Masa Jabatan Presiden Perlu Dibatasi? ,http:/ / www. tempo.co/read/news/2010/08/19/078272307/Kenapa-Masa-JabatanPresiden-Perlu-Dibatasi diakses pada tanggal 16 juni 2013.

Boy Yendra Tamin, Sisi Lain Dari Gagasan Perubahan Periode Jabatan Presiden, http:/ / boyyendratamin.blogspot.com/2011/03/ sisi-lain-darigagasan-perubahan.html, diakses pada tanggal 16 juni 2013.

\section{Peraturan Perundang-Undangan}

Undang Undang Dasar Republik Indonesia 1945.

UU Nomor 32 Tahun 2004

Undang-Undang Nomor 5 Tahun 1974.

Surat Keputusan Ketua Mahkamah Agung Republik Indonesia No. 19/ KMA/ SK/ II/ 2012 tentang Peraturan Tata Tertib Pemilihan Ketua Mahkamah Agung.

Peraturan Mahmakah Konstitusi Nomor 3 Tahun 2012 